\title{
Characterization of semipurified enterocins produced by Enterococcus faecium strains isolated from raw camel milk
}

\author{
Rita Rahmeh, ${ }^{1}$ Abrar Akbar, Mohamed Kishk, Thanyan Al Onaizi, Aisha Al-Shatti, Anisha Shajan, \\ Batool Akbar, Salwa Al-Mutairi, and Awatef Yateem \\ Biotechnology Program, Environment and Life Sciences Research Center, Kuwait Institute for Scientific Research, PO Box 24885, Safat, \\ 13109 Kuwait
}

\section{ABSTRACT}

Food safety has become an issue of great interest worldwide. Listeria monocytogenes is a food-borne pathogen that causes listeriosis and is difficult to control in the dairy industry. The use of lactic acid bacteria (LAB) and their antimicrobial substances against Listeria is promising in food applications. Here, we report the isolation from raw camel milk of LAB displaying antilisterial activity. Two isolates were selected for their secretion of bacteriocin(s) and identified by $16 \mathrm{~S}$ rRNA sequencing as Enterococcus faecium S6 and R9. The produced bacteriocins were partially purified by ammonium sulfate precipitation and then biochemically characterized. Antimicrobial activity was estimated to be 6,400 and $400 \mathrm{AU}$ (arbitrary units) $/ \mathrm{mL}$ for $E$. faecium S6 and R9, respectively. The proteinaceous nature of the bacteriocins was confirmed via enzymatic reactions. Moreover, lipolytic and glycolytic enzymes completely inactivated the antimicrobial effect of the bacteriocins. These bacteriocins were heat-resistant and stable over a wide range of $\mathrm{pH}$ (2.0 to 10.0). To confirm its inactivation by lipolytic and glycolytic enzymes, the bacteriocin of E. faecium S6 was further purified by gel filtration, which suggested the existence of carbohydrate and lipid moieties. In addition, enterocin-coding genes were identified by PCR, showing DNA fragments corresponding in size to enterocins $\mathrm{A}, \mathrm{B}$, and $\mathrm{P}$ for $E$. faecium $\mathrm{S} 6$ and to enterocins $\mathrm{B}$ and $\mathrm{P}$ for E. faecium R9. In conclusion, these results indicate that partially purified bacteriocins from E. faecium $\mathrm{S} 6$ and R9 may be beneficial in controlling Listeria in the dairy industry. Key words: lactic acid bacteria, listeriosis, enterocin, camel milk

Received October 16, 2017.

Accepted January 22, 2018

${ }^{1}$ Corresponding author: rrahmeh@kisr.edu.kw

\section{INTRODUCTION}

Milk is a highly nutritious food, providing an ideal environment for the growth of a diverse and complex microbial population. Lactic acid bacteria (LAB) are a dominant population in raw milk (Quigley et al., 2013). Beside their wide utilization in food fermentation processes (Do Carmo et al., 2012), they play a key role in food preservation through the production of antimicrobial compounds. They are known to secrete ribosomally synthesized peptides called bacteriocins that display antimicrobial activity against closely related species (Drider et al., 2006). Today, bacteriocins are extensively used in preservation of a variety of food products of animal and vegetable origin against a wide range of food-borne pathogenic and spoilage bacteria (Galvez et al., 2008).

Among LAB, the genus Enterococcus is of particular interest (Khan et al., 2010). It is found particularly in the intestine of humans and animals but also in many food products, including milk. Many Enterococcus species are reported to produce bacteriocins that are often named "enterocins." According to the classification scheme reported by Franz et al. (2007) based on amino acid sequence homologies, the enterocins are divided into 4 major classes: lantibiotic enterocins (class I); non-lantibiotic enterocins (class II); cyclic enterocins (class III); and large thermolabile bacteriocins (class IV). Enterocins A, B, P, and L50 belong to class II of bacteriocins, and enterocins $\mathrm{A}$ and $\mathrm{P}$ are enterocins of the pediocin family. Enterocin L50 is synthesized without a leader peptide and enterocin B is a linear nonpediocin-like enterocin. Enterocins that are effective against Listeria are promising natural antimicrobial agents in food preservation. Listeria monocytogenes is a common pathogen widely distributed in nature and found in meat and dairy products, where it causes foodborne diseases. Listeria monocytogenes has been associated with many food-borne outbreaks and is considered an important issue for food safety and public health (De Buyser et al., 2001). Listeria monocytogenes is difficult 
to control in the food industry because of its growth characteristics, being highly salt-tolerant and able to grow at temperatures ranging from 1 to $45^{\circ} \mathrm{C}$ (Camargo et al., 2017). Many enterocin-producing strains, such as Enterococcus faecium F58, have been isolated and used as antilisterial agents in cheese without the use of synthetic chemical preservatives (Achemchem et al., 2006). Previous studies indicated the potential of using the bacteriocin-producing E. faecium WHE 81 as a culture adjunct to inhibit L. monocytogenes during cheese manufacturing (Izquierdo et al., 2009). Moreover, semipurified forms of enterocins have also been explored as preservatives in various foods, especially in unfermented products (Khan et al., 2010).

Although several bacteriocins have been isolated from different natural sources, the identification of new bacteriocin-producing strains or their bacteriocins is necessary to control food pathogens. A large number of bacteriocins produced by Enterococcus have been described and many have been characterized at the biochemical and genetic level (Franz et al., 2007). A recent study described several Enterococcus isolates that harbored at least one enterocin-encoding gene and exhibited enterocin activity (Ogaki et al., 2016). A large spectrum and multiple bacteriocin-producing E. faecium strains have been isolated from raw bovine milk and characterized (Gaaloul et al., 2015). Moreover, a bacteriocin produced by E. faecium ICIS8 has been purified and its mode of action characterized (Vasilchenko et al., 2017). However, few studies have been carried out on the isolation of bacteriocin-producing strains from raw camel milk, which presents specific biological characteristics and beneficial traits (Vimont et al., 2017). Only limited information is available about the bacteriocins produced by strains isolated from this source.

The present study reports the isolation of E. faecium strains producing multiple enterocins from raw camel milk. These E. faecium isolates were partially purified and their enterocins biochemically characterized.

\section{MATERIALS AND METHODS}

\section{Isolation and Screening of $L A B$ for Antilisterial Activity}

The LAB were isolated from 50 samples of raw camel milk collected from local farmers in Al-Wafra (southernmost area, Kuwait) and Kabad (northwest region, Kuwait). All samples were transported to the laboratory in an icebox and analyzed immediately. The samples were homogenized in a sterile saline buffer $(10$ $\mathrm{mL}$ of milk in $90 \mathrm{~mL}$ of saline buffer $(0.85 \% \mathrm{NaCl}$, wt/ vol; Sigma-Aldrich, St. Louis, MO) and plated on de
Man, Rogosa, and Sharpe (MRS) agar (Thermo Fisher Scientific, Waltham, MA; Ao et al., 2012). The plates were incubated at $37^{\circ} \mathrm{C}$ for $48 \mathrm{~h}$ under anaerobic conditions. After incubation, the colonies were enumerated and representative colonies (about 10\% of the observed count) were selected from each sample.

The isolates were tested for catalase and oxidase activity, Gram reaction, and cell morphology after incubation on MRS agar for $24 \mathrm{~h}$. Isolates possessing typical LAB characteristics (gram-positive, catalase-negative, oxidase-negative) were inoculated into MRS broth (Thermo Fisher Scientific) and streaked to obtain pure cultures. Pure isolates were screened for antimicrobial activity against $L$. monocytogenes ATCC 7644 using the spot-on-the-lawn method as described by Hoover and Harlander (1993). Briefly, LAB isolates were cultured in MRS broth at $30^{\circ} \mathrm{C}$ for $24 \mathrm{~h}$, after which $1-\mu \mathrm{L}$ aliquots were spotted on the surface of MRS agar and incubated at $37^{\circ} \mathrm{C}$ for $24 \mathrm{~h}$ under anaerobic conditions. Subsequently, culture medium containing $0.8 \%$ (wt/ vol) agar (Thermo Fisher Scientific) was inoculated with L. monocytogenes $\left(10^{7} \mathrm{cfu} / \mathrm{mL}\right)$ and overlaid on the LAB-spotted plates. After incubation at the conditions required for growth of $L$. monocytogenes (overnight at $37^{\circ} \mathrm{C}$ ), the presence of inhibitory zones (clear zones) was recorded as an indicator of the antimicrobial activity of the tested isolates. The inhibitory zone diameter around the well was measured and expressed in millimeters.

\section{Determination of Production of Antimicrobial Compounds}

Among all isolates, LAB strains having antimicrobial activity against L. monocytogenes ATCC 7644 were tested for their ability to produce antimicrobial substances by the well-diffusion assay, as described by Tagg and McGiven (1971).

Cell-free supernatants (CFS) were prepared as follows: overnight cultures of each isolate were used to inoculate (1\% vol/vol) $10 \mathrm{~mL}$ of MRS broth. After 24 $\mathrm{h}$ of incubation at $37^{\circ} \mathrm{C}$, cells were removed by centrifugation $\left(7,000 \times g\right.$ at $4^{\circ} \mathrm{C}$ for $\left.15 \mathrm{~min}\right)$. The $\mathrm{pH}$ of the obtained CFS was adjusted to 6.5 with $1 M \mathrm{NaOH}$ (Sigma-Aldrich) to exclude the effects of organic acids. Neutralized CFS was treated with catalase $(1 \mathrm{mg} /$ $\mathrm{mL}$; Sigma-Aldrich) to eliminate the inhibitory effect of $\mathrm{H}_{2} \mathrm{O}_{2}$. The CFS was filter-sterilized $(0.22-\mu \mathrm{m}$ pore size, Merck Millipore, Burlington, MA) to remove any viable cells. Wells were made in $0.7 \%$ agar plates inoculated with L. monocytogenes ATCC 7644 at a final concentration of about $10^{7} \mathrm{cfu} / \mathrm{mL}$ and were filled with $80 \mu \mathrm{L}$ of CFS. The plates were incubated over- 
night at $37^{\circ} \mathrm{C}$ (conditions required for the growth of $L$. monocytogenes ATCC 7644). Results of 3 assays were determined by measuring the diameter of the clear zone (in $\mathrm{mm}$ ) around the wells. Zones of inhibition $>5 \mathrm{~mm}$ were considered positive.

Bacteriocinogenic activity was measured by the welldiffusion assay following a 2-fold serial dilution of the CFS. The titer, in arbitrary units per milliliter (AU/ $\mathrm{mL}$ ), was defined as the reciprocal of the highest 2-fold dilution providing a distinct inhibition zone (MayrHarting et al., 1972; Hernández et al., 2005).

\section{Molecular Identification of Strains Producing Antimicrobial Compounds}

Among all isolates, only bacteriocinogenic LAB were identified at the molecular level by $16 \mathrm{~S}$ rRNA sequencing. Genomic DNA extraction from overnight culture of LAB was carried out using MasterPure gram-positive DNA purification kits (Epicenter Biotechnologies, Hessisch Oldendorf, Germany) according to the manufacturer's instructions. The PCR-mediated amplification of $16 \mathrm{~S}$ rDNA and purification of the PCR products was carried out as described previously (Rainey et al., 1996). Purified PCR products were sequenced using BigDye Terminator v1.1 Cycle Sequencing Kit (Applied Biosystems, Waltham, MA) as directed in the manufacturer's protocol. Sequence reactions were electrophoresed using the 3500xL Genetic Analyzer (Applied Biosystems). The resulting sequence data from the strains were analyzed using Molecular Evolutionary Genetic Analysis version 7 (MEGA7; Kumar et al., 2016), the EzTaxon server (Myers and Miller, 1988; Altschul et al., 1997; Kim et al., 2012) and BlastN (Altschul et al., 1990) and then compared with representative $16 \mathrm{~S}$ rRNA gene sequences from the EMBL (http://www.ebi .ac.uk/embl/) database or RDP (http://rdp.cme.msu .edu/; Maidak et al., 1999) to determine the identity of the strains by their similarity to reference strains.

\section{Partial Purification of Bacteriocins}

Ammonium sulfate precipitation was performed according to Kumari et al. (2012) with minor modifications. Briefly, bacteriocinogenic LAB strains were grown in $1 \mathrm{~L}$ of $\mathrm{MRS}$ broth at $37^{\circ} \mathrm{C}, \mathrm{pH} 6.5$, for 24 $\mathrm{h}$. The culture supernatant was collected by centrifugation at $7,000 \times g$ for $15 \mathrm{~min}$ at $4^{\circ} \mathrm{C}$. Ammonium sulfate (Sigma-Aldrich) was added slowly to the culture supernatant with constant stirring to achieve $40 \%$ saturation. The mixture was kept at $4^{\circ} \mathrm{C}$ for $4 \mathrm{~h}$ and then centrifuged at $10,000 \times g$ for $30 \mathrm{~min}$ at $4^{\circ} \mathrm{C}$; the pellet was dissolved in $0.05 \mathrm{M}$ sodium phosphate buffer $(\mathrm{pH}$ 7.0). The supernatant was brought to 60,80 , and $100 \%$ saturation by the addition of ammonium sulfate, and the precipitates were treated as described above. The dissolved pellets were tested for antilisterial activity using the well-diffusion assay (Tagg and McGiven, 1971). After ammonium sulfate precipitation, partially purified bacteriocins were subjected to further purification by gel filtration chromatography (Superdex 75 10/300 GL, GE Healthcare Life Sciences, Little Chalfont, UK). Twenty-eight fractions of $0.5 \mathrm{~mL}$ were collected on the chromatogram between 7 and $21 \mathrm{~mL}$. The antimicrobial activity of the partially purified antimicrobial peptide $(1 \mu \mathrm{g})$ against L. monocytogenes ATCC 7644 was assayed by the agar well-diffusion method (Tagg and McGiven, 1971).

\section{Effect of Enzymes, $\mathrm{pH}$, and Temperature on Bacteriocin Activity}

To assay the susceptibility of bacteriocins to various enzymes, the partially purified bacteriocins were treated with the following enzymes (Sigma-Aldrich): trypsin, $\alpha$-chymotrypsin, proteinase $\mathrm{K}$, papain, $\alpha$-amylase, lipase, and protease. Each enzyme was dissolved in $10 \mathrm{~m} M$ potassium phosphate buffer ( $\mathrm{pH} \mathrm{6.8}$; final concentration of $1 \mathrm{mg} / \mathrm{mL}$ ). Following incubation at $37^{\circ} \mathrm{C}$ for $2 \mathrm{~h}$, reactions were heated at $80^{\circ} \mathrm{C}$ for 10 min to denature the enzymes and assayed for activity. As a control, a sample was treated with the enzyme buffer. To determine thermal stability, the bacteriocins were first heated for $3 \mathrm{~h}$ at $37^{\circ} \mathrm{C}, 60 \mathrm{~min}$ at $60^{\circ} \mathrm{C}$ and $80^{\circ} \mathrm{C}, 30 \mathrm{~min}$ and $60 \mathrm{~min}$ at $100^{\circ} \mathrm{C}$ and $15 \mathrm{~min}$ at $121^{\circ} \mathrm{C}$, and then cooled and assayed for activity. An unheated control sample was kept at $4^{\circ} \mathrm{C}$.

The effect of $\mathrm{pH}$ on the bacteriocins was tested by adjusting the $\mathrm{pH}$ level between 2 and 10 (at increments of $2 \mathrm{pH}$ units) with sterile $1 \mathrm{~N} \mathrm{NaOH}$ or $1 N \mathrm{HCl}$. Following incubation at $37^{\circ} \mathrm{C}$ for $1 \mathrm{~h}$, the samples were adjusted to $\mathrm{pH} 6.5$ and tested for antilisterial activity. Untreated sample served as control (Zhu et al., 2000).

\section{Molecular Analysis of Enterocin Genes}

Bacteriocinogenic LAB strains identified as E. faecium were screened by PCR for detection of enterocin A, B, P, and L50 genes as described by Park et al. (2003) using enterocin-specific primers (du Toit et al., 2000; Park et al., 2003). Genomic DNA extraction from an overnight culture of LAB was carried out using genElute bacterial genomic DNA kit (Sigma-Aldrich), according to the manufacturer's instructions. The PCR 
conditions consisted of an initial denaturing step for 2 min at $95^{\circ} \mathrm{C}$, followed by 30 cycles at $95^{\circ} \mathrm{C}$ for $1 \mathrm{~min}$, annealing at $52^{\circ} \mathrm{C}$ for $2 \mathrm{~min}$, and elongation at $72^{\circ} \mathrm{C}$ for $3 \mathrm{~min}$, followed by final extension at $72^{\circ} \mathrm{C}$ for $7 \mathrm{~min}$. The presence and molecular size of the PCR products were analyzed by electrophoresis on $2 \%$ agarose gels, stained with ethidium bromide and visualized under UV illumination.

\section{RESULTS AND DISCUSSION}

\section{Antilisterial Activity of Bacteriocinogenic $L A B$}

A total of 100 bacterial colonies were isolated from raw camel milk on MRS and characterized as having typical LAB characteristics (gram-positive, catalase-negative, oxidase-negative). From this LAB collection, 81 isolates showed antibacterial activity against $L$. monocytogenes ATCC 7644. Evaluation of the antimicrobial activity of CFS from these isolates neutralized at $\mathrm{pH} 6.5$ showed that only 2 isolates, S6 and R9, potentially produced bacteriocins. The diameters of inhibition zone were 21 and $18 \mathrm{~mm}$ for $\mathrm{S} 6$ and R9, respectively, and antibacterial activity was estimated at 6,400 and $400 \mathrm{AU} / \mathrm{mL}$ for S6 and R9, respectively.

\section{Molecular Identification}

Isolates $\mathrm{S} 6$ and R9 were identified molecularly by complete $16 \mathrm{~S}$ rRNA sequence by direct sequencing of PCR-amplified 16S rRNA. The obtained sequences were compared with rRNA sequences deposited in the EMBL or RDP database (Maidak et al., 1999). The sequences of S6 and R9 were identified as E. faecium at an identity of 99.9 and $100.0 \%$, respectively.

\section{Partial Purification and Characterization of Bacteriocins}

Partial Purification and Enzyme Effect. The bacteriocins produced by E. faecium S6 and R9 were partially purified from culture supernatants by using $40 \%$ ammonium sulfate. To determine the biochemical and biophysical properties of these antimicrobial compounds, the partially purified bacteriocins were tested for sensitivity to different enzymes, temperatures, and $\mathrm{pH}$ values. Results of 3 assays were determined by measuring the diameter of the clear zone around the wells (Table 1).

Enzyme sensitivity assays demonstrated that the inhibitory activity of the bacteriocins produced by $E$.

Table 1. Effect of enzymes, pH, and heat on antilisterial activity of bacteriocins from Enterococcus faecium S6 and R9 isolates ${ }^{1}$

\begin{tabular}{|c|c|c|c|c|}
\hline \multirow[b]{2}{*}{ Treatment } & \multicolumn{2}{|c|}{ IA $(\mathrm{AU} / \mathrm{mL})$ of bacteriocins } & \multicolumn{2}{|c|}{ IZD $(\mathrm{mm})$ of bacteriocins } \\
\hline & S6 isolate & $\mathrm{R} 9$ isolate & S6 isolate & $\mathrm{R} 9$ isolate \\
\hline \multicolumn{5}{|l|}{ Enzymes } \\
\hline Control $^{2}$ & 800 & 400 & $21 \pm 0.3$ & $18 \pm 0.3$ \\
\hline$\alpha$-Chymotrypsin & - & - & - & - \\
\hline Proteinase K & - & - & - & - \\
\hline Papain & - & - & - & - \\
\hline Trypsin & - & - & - & - \\
\hline Protease & - & - & - & - \\
\hline Lipase & - & - & - & - \\
\hline$\alpha$-Amylase & - & - & - & - \\
\hline \multicolumn{5}{|l|}{$\mathrm{pH}$} \\
\hline Control $^{2}$ & 6,400 & 400 & $17 \pm 0.3$ & $18 \pm 0.3$ \\
\hline 2 & + & + & $17 \pm 0.3$ & $18 \pm 0.5$ \\
\hline 6 & + & + & $17 \pm 0.3$ & $18 \pm 0.3$ \\
\hline 8 & + & + & $17 \pm 0.3$ & $18 \pm 0.3$ \\
\hline 10 & + & + & $17 \pm 0.3$ & $18 \pm 0.5$ \\
\hline \multicolumn{5}{|l|}{ Heat/time } \\
\hline Control $^{2}$ & 6,400 & 400 & $17 \pm 0.3$ & $18 \pm 0.3$ \\
\hline $37^{\circ} \mathrm{C} / 180 \mathrm{~min}$ & + & + & $17 \pm 0.3$ & $18 \pm 0.3$ \\
\hline $60^{\circ} \mathrm{C} / 30 \mathrm{~min}$ & + & + & $17 \pm 0.3$ & $18 \pm 0.3$ \\
\hline $80^{\circ} \mathrm{C} / 30 \mathrm{~min}$ & + & + & $17 \pm 0.3$ & $18 \pm 0.3$ \\
\hline $100^{\circ} \mathrm{C} / 30 \mathrm{~min}$ & + & + & $17 \pm 0.3$ & $17 \pm 0.3$ \\
\hline $100^{\circ} \mathrm{C} / 60 \mathrm{~min}$ & + & + & $17 \pm 0.5$ & $17 \pm 0.3$ \\
\hline $121^{\circ} \mathrm{C} / 15 \mathrm{~min}$ & + & + & $17 \pm 0.5$ & $17 \pm 0.3$ \\
\hline Storage $90 \mathrm{~d}$ at $4^{\circ} \mathrm{C}$ & + & + & $20 \pm 0.3$ & Not tested \\
\hline
\end{tabular}


faecium S6 and R9 was eliminated after treatment with trypsin, $\alpha$-chymotrypsin, proteinase $\mathrm{K}$, protease, papain, and protease (Table 1). These results confirmed the proteinaceous nature of these antimicrobial substances. Interestingly, treatment of bacteriocins from E. faecium $\mathrm{S} 6$ and $\mathrm{R} 9$ with $\alpha$-amylase and lipase induced a loss of activity, indicating that bacteriocins produced by these strains may require a glucosidic and a lipidic moiety present in the culture medium for their biological activity or that they may be glycoproteins containing lipid and carbohydrate moieties (Hernández et al., 2005). To rule out the possibility that glucosidic and lipidic moieties are present in the culture medium, the bacteriocin from E. faecium S6 was subjected to further purification by gel filtration chromatography (Superdex 75 10/300 GL, GE Healthcare Life Sciences). Figure 1 shows the chromatography profile of the bacteriocins from E. faecium S6. Collected fractions were assayed for antimicrobial activity by the agar well-diffusion method. Active fractions were detected as 3 peaks on the chromatogram between 16.5 and $19 \mathrm{~mL}$. This elution volume corresponds to a molecular weight between 1.3 and $6.5 \mathrm{kDa}$ according to the calibration. These 3 peaks were subjected again to chromatography, and their antilisterial activity was confirmed (Figure 1). The treatment of the active fractions with $\alpha$-amylase and lipase resulted in a loss of their antilisterial activity. These results strongly suggest a possible post-translational modification of the bacteriocin produced by E. faecium S6. However, this fact needs to be confirmed by structural characterization of this bacteriocin. To date, only 3 bacteriocins have been reported to be glycosylated: glycocin F produced by Lactobacillus plantarum KW30 (Stepper et al., 2011), sublancin 168 produced by $B a-$ cillus subtilis 168 (Oman et al., 2011), and enterocin F4-9 produced by Enterococcus faecalis F4-9 (Maky et
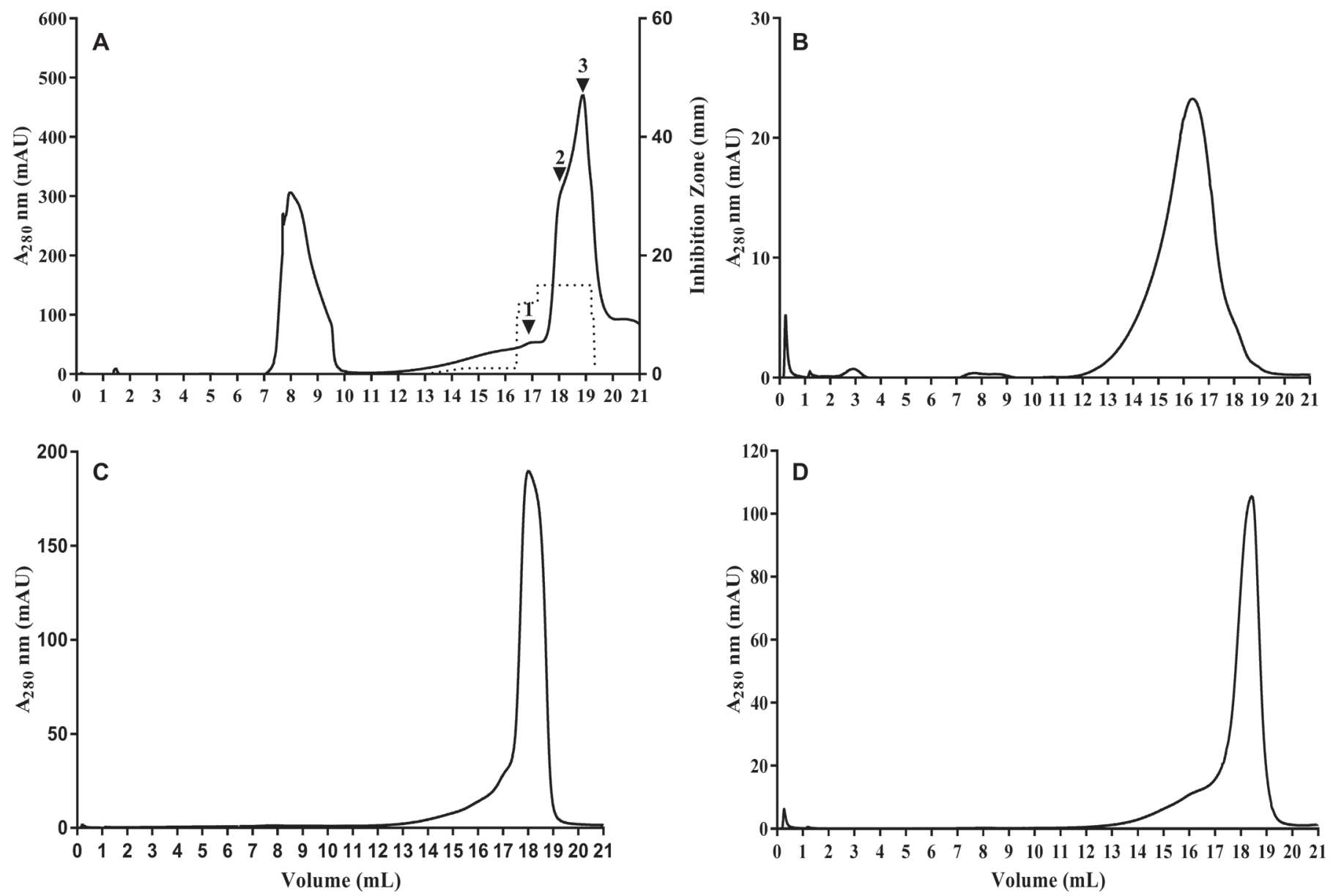

Figure 1. Purification of bacteriocins obtained from Enterococcus faecium S6 culture supernatant after ammonium sulfate precipitation by gel filtration chromatography using Superdex 75 10/300 GL (GE Healthcare Life Sciences, Little Chalfont, UK). (A) The peaks with antimicrobial activity were observed at 16.5 to $19 \mathrm{~mL}(\mathbf{\nabla})$. Panels B, C, and D correspond to chromatograms of peaks 1, 2, and 3, respectively. Absorbance was measured at $280 \mathrm{~nm}$ (arbitrary units, AU). The dot plot area represents the inhibition zone diameter of fractions (mm). 
al., 2015); another enterocin (SH01, from E. faecium SH01) has been reported to be sensitive to $\alpha$-amylase. This indicates that several enterocins (glycocin F, sublancin 168, and F4-9) probably belong to group IV, which contain carbohydrate and lipid moieties in their structure (Heredia-Castro et al., 2015).

Temperature Effect. The bacteriocins produced by E. faecium $\mathrm{S} 6$ and $\mathrm{R} 9$ were heat-stable. They retained $100 \%$ of antilisterial activity after heating for $3 \mathrm{~h}$ at $37^{\circ} \mathrm{C}, 60 \mathrm{~min}$ at $60^{\circ} \mathrm{C}$ and $80^{\circ} \mathrm{C}, 30 \mathrm{~min}$ and $60 \mathrm{~min}$ at $100^{\circ} \mathrm{C}$, and $15 \mathrm{~min}$ at $121^{\circ} \mathrm{C}$ compared with that of the control sample kept at $4^{\circ} \mathrm{C}$ (Table 1). Our results are in agreement with several studies showing stability of bacteriocins to autoclaving (Han et al., 2013). The heat stability of these bacteriocins may be attributed to the ecological and environmental adaptation of the producing strains E. faecium S6 and R9, which were isolated from camels living in a hot, arid environment (Heredia-Castro et al., 2015).

$p \boldsymbol{H}$ and Storage Effects. The antilisterial activity of the bacteriocins produced by E. faecium $\mathrm{S} 6$ and R9 was retained over a $\mathrm{pH}$ range of 2.0 to 10.0 (Table
$1)$. These results were similar to that of enterocin B produced by E. faecium ALP7 (Pinto et al., 2009). The antilisterial activity of the bacteriocin produced by $E$. faecium $\mathrm{S} 6$ was retained after storage at $4^{\circ} \mathrm{C}$ for $90 \mathrm{~d}$.

Taken together, these results indicate that the bacteriocins produced by E. faecium $\mathrm{S} 6$ and R9 are of technological importance for use in the dairy industry as natural biopreservatives in pasteurized foods and fermented milk products.

\section{Molecular Analysis of Enterocin Genes}

Following PCR, products of about 130, 160, and 120 $\mathrm{bp}$, respectively, corresponding to the specific amplified regions of enterocin $\mathrm{A}$, enterocin $\mathrm{B}$, and enterocin $\mathrm{P}$ were amplified from the DNA of E. faecium S6 (Figure 2). Two bands of about 160 and 120 bp were amplified from DNA of $E$. faecium R9 using primers for enterocin $\mathrm{B}$ and enterocin P. Other primers used in this study did not yield any visible bands. These results indicate that E. faecium $\mathrm{S} 6$ contains enterocin $\mathrm{A}, \mathrm{B}$, and $\mathrm{P}$ genes, whereas E. faecium R9 harbors enterocin $\mathrm{B}$ and $\mathrm{P}$

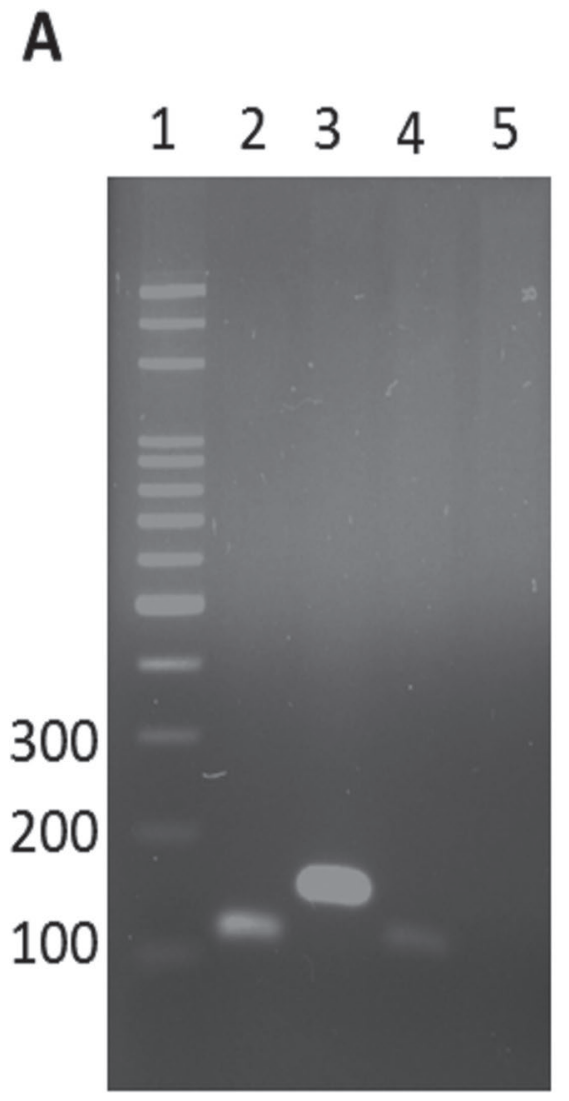

\section{B}

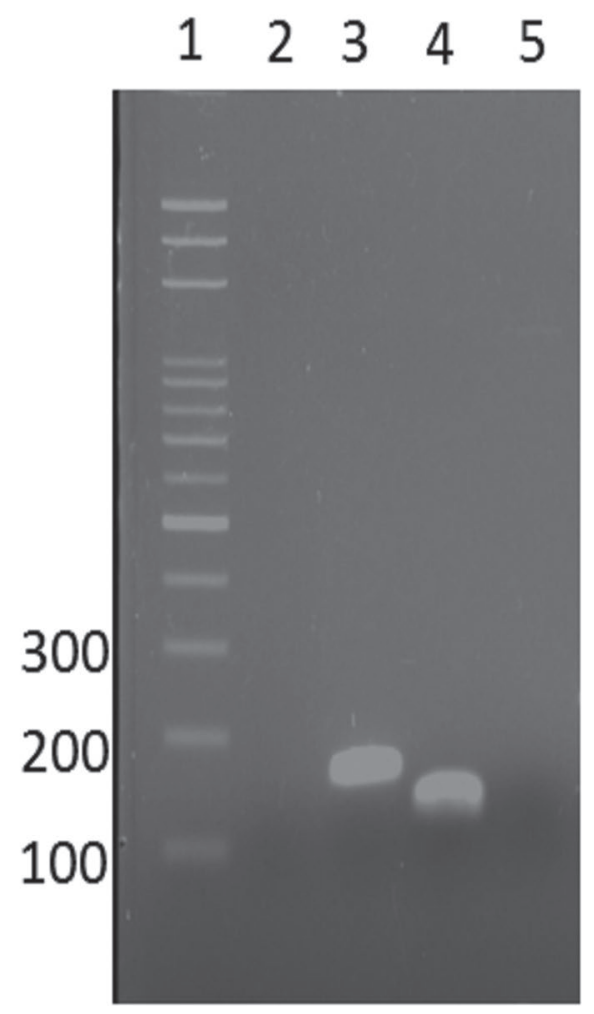

Figure 2. The PCR products generated from DNA of Enterococcus faecium S6 (A) and E. faecium R9 (B) using primers specific for different enterocins: lane $1=100$-bp ladder; $2=$ enterocin A primers; $3=$ enterocin B primers; $4=$ enterocin P primers $(\mathrm{P} 1) ; 5=$ enterocin L50 primers. 
genes. The production of multiple enterocins could be a common trait among enterococci. Many E. faecium are able to produce multiple bacteriocins, such as $E$. faecium GGN7 (Gaaloul et al., 2015), E. faecium JCM $5804 \mathrm{~T}$ (Park et al., 2003), and E. faecium LCW 44 (Vimont et al., 2017). The presence of multiple bacteriocin genes does not necessarily mean that all bacteriocins are expressed at the same time but bacteriocins could be expressed sequentially and the presence of some bacteriocins may regulate the expression of other bacteriocins (Perez et al., 2012). To ensure proper production of a bacteriocin, the full expression machinery must be present in the genome. The enterocin A (entA) gene is the first enterocin that was characterized to be located in an operon with the immunity gene (entI), and 3 component regulatory systems [the peptide pheromone gene $(e n t F)$, the histidine protein kinase gene (entK), and the response regulator (entR); O'Keeffe et al., 1999]. This operon is associated with another secretory operon that consists of $\mathrm{ABC}$ transporter (entT) and its accessory gene (entD; O'Keeffe et al., 1999). On the other hand, the enterocin $\mathrm{P}$ gene is processed and secreted by the general secretory pathway known as sec-dependent pathway, and this gene is associated with immunity protein (entiP) downstream to the enterocin $\mathrm{P}$ gene (Cintas et al., 1997). Moreover, entB is associated with an immunity gene (entiB) that is present in the upstream region of entB (Hu et al., 2010).

Enterocins A and P belong to class IIa (pediocin-like) bacteriocins, which are cationic, have very efficient antilisterial activity, and permeabilize the cell membrane to kill target cells (Brandão et al., 2010). Enterococcus faecium $\mathrm{S} 6$ has antilisterial activity significantly greater than E. faecium R9, probably due to the synergistic activity of enterocins A and B, because E. faecium S6 contains both enterocins (Casaus et al., 1997).

Some Enterococcus strains show the presence of different virulence genes such as aggregation substance and gelatinase production (Chuang et al., 2009), in addition to antibiotic resistant genes such as vancomycin (Arias and Murray, 2012). Thus, the application of a live probiotic culture of Enterococcus is not recommended because of its ability to disseminate and acquire antibiotic resistance genes (Henning et al., 2015). However, the use of bacteriocins from enterococci as food preservatives could help in overcoming this problem associated with the use of live bacterial culture of Enterococcus.

\section{CONCLUSIONS}

Although several bacteriocinogenic LAB have been isolated from different sources, there is a constant demand for the identification of new strains or bacterio- cins that target food pathogens. These natural antimicrobials may be useful in overcoming the resistance to conventional antibiotics. The screening of LAB isolates from raw camel milk revealed 2 strains of E. faecium, $\mathrm{S} 6$ and R9, that produced bacteriocins. Isolates of $E n$ terococcus are typically present in camel milk because of the high salt presence in this milk compared with milk of other livestock animals. Analysis of biochemical properties and genetic variation between E. faecium S6 and R9 confirmed the wide variability between these 2 isolates, even when they were genetically identified as E. faecium. The biochemical properties of the semipurified bacteriocins produced by these strains (e.g., stability over a wide range of $\mathrm{pH}$ and temperature, sensitivity to protease, and activity against L. monocytogenes) make them interesting candidates for applications in food preservation. Our future direction is to test the bacteriocinogenic effect of the produced bacteriocins on several Listeria strains to support their potential application in food preservation.

\section{ACKNOWLEDGMENTS}

The authors thank the Kuwait-MIT Center for Natural Resources and the Environment (CNRE, Cambridge, MA), Kuwait Foundation for the Advancement of Sciences (KFAS, Kuwait City, Kuwait), and Kuwait Institute for Scientific Research (Kuwait City, Kuwait) for their financial support. The technical assistance of Riaz Al-Dawi (Kuwait Institute for Scientific Research) is gratefully acknowledged.

\section{REFERENCES}

Achemchem, F., J. Abrini, M. Martinez-Bueno, E. Valdivia, and M. Maqueda. 2006. Control of Listeria monocytogenes in goat's milk and goat's jben by the bacteriocinogenic Enterococcus faecium F58 strain. J. Food Prot. 69:2370-2376. https://doi.org/10.4315/0362 $-028 \mathrm{x}-69.10 .2370$

Altschul, S. F., W. Gish, W. Miller, E. W. Myers, and D. J. Lipman. 1990. Basic local alignment search tool. J. Mol. Biol. 215:403-410. https://doi.org/10.1016/S0022-2836(05)80360-2.

Altschul, S. F., T. L. Madden, A. A. Schaffer, J. Zhang, Z. Zhang, W Miller, and D. J. Lipman. 1997. Gapped BLAST and PSI-BLAST: A new generation of protein database search programs. Nucleic Acids Res. 25:3389-3402. https://doi.org/10.1093/nar/25.17.3389.

Ao, X., X. Zhang, X. Zhang, L. Shi, K. Zhao, J. Yu, L. Dong, Y. Cao, and Y. Cai. 2012. Identification of lactic acid bacteria in traditional fermented yak milk and evaluation of their application in fermented milk products. J. Dairy Sci. 95:1073-1084. https://doi .org $/ 10.3168 /$ jds.2011-4224.

Arias, C. A., and B. E. Murray. 2012. The rise of the Enterococcus: Beyond vancomycin resistance. Nat. Rev. Microbiol. 10:266-278. https://doi.org/10.1038/nrmicro2761.

Brandão, A., T. Almeida, E. Munoz-Atienza, C. Torres, G. Igrejas, P. E. Hernandez, L. M. Cintas, P. Poeta, and C. Herranz. 2010. Antimicrobial activity and occurrence of bacteriocin structural genes in Enterococcus spp. of human and animal origin isolated in 
Portugal. Arch. Microbiol. 192:927-936. https://doi.org/10.1007/ s00203-010-0619-z.

Camargo, A. C., J. J. Woodward, D. R. Call, and L. A. Nero. 2017. Listeria monocytogenes in food-processing facilities, food contamination, and human listeriosis: The Brazilian scenario. Food-borne Pathog. Dis. 14:623-636. https://doi.org/10.1089/fpd.2016.2274.

Casaus, P., T. Nilsen, L. M. Cintas, I. F. Nes, P. E. Hernandez, and H. Holo. 1997. Enterocin B, a new bacteriocin from Enterococcus faecium T136 which can act synergistically with enterocin $\mathrm{A}$. Microbiology 143:2287-2294. https://doi.org/10.1099/00221287-143 $-7-2287$.

Chuang, O. N., P. M. Schlievert, C. L. Wells, D. A. Manias, T. J. Tripp, and G. M. Dunny. 2009. Multiple functional domains of Enterococcus faecalis aggregation substance Asc10 contribute to endocarditis virulence. Infect Immun. 77:539-548. https://doi.org/ 10.1128/IAI.01034-08.

Cintas, L. M., P. Casaus, L. S. Havarstein, P. E. Hernandez, and I. F. Nes. 1997. Biochemical and genetic characterization of enterocin P, a novel sec-dependent bacteriocin from Enterococcus faecium P13 with a broad antimicrobial spectrum. Appl. Environ. Microbiol. 63:4321-4330. https://doi.org/10.1128/jb.182.23.6806-6814.2000.

De Buyser, M. L., B. Dufour, M. Maire, and V. Lafarge. 2001. Implication of milk and milk products in food-borne diseases in France and in different industrialised countries. Int. J. Food Microbiol. 67:1-17. https://doi.org/10.1016/s0168-1605(01)00443-3.

Do Carmo, A. P., M. N. De Oliveira, D. F. Da Silva, S. B. Castro, A. C. Borges, A. F. De Carvalho, and C. A. De Moraes. 2012. Genes involved in lactose catabolism and organic acid production during growth of Lactobacillus delbrueckii UFV H2b20 in skimmed milk. Benef. Microbes 3:23-32. https://doi.org/10.3920/BM2011.0037.

Drider, D., G. FimLand, Y. Hechard, L. M. McMullen, and H. Prevost. 2006. The continuing story of class IIa bacteriocins. Microbiol. Mol. Biol. Rev. 70:564-582. https://doi.org/10.1128/MMBR .00016-05.

du Toit, M., C. M. Franz, L. M. Dicks, and W. H. Holzapfel. 2000. Preliminary characterization of bacteriocins produced by Enterococcus faecium and Enterococcus faecalis isolated from pig faeces. J. Appl. Microbiol. 88:482-494. https://doi.org/10.1046/j.1365 $-2672.2000 .00986 . x$

Franz, C. M., M. J. van Belkum, W. H. Holzapfel, H. Abriouel, and A. Galvez. 2007. Diversity of enterococcal bacteriocins and their grouping in a new classification scheme. FEMS Microbiol. Rev. 31:293-310. https://doi.org/10.1111/j.1574-6976.2007.00064.x.

Gaaloul, N., O. ben Braiek, K. Hani, A. Volski, M. L. Chikindas, and T. Ghrairi. 2015. Isolation and characterization of large spectrum and multiple bacteriocin-producing Enterococcus faecium strain from raw bovine milk. J. Appl. Microbiol. 118:343-355. https:// doi.org/10.1111/jam.12699.

Galvez, A., R. L. Lopez, H. Abriouel, E. Valdivia, and N. B. Omar. 2008. Application of bacteriocins in the control of food-borne pathogenic and spoilage bacteria. Crit. Rev. Biotechnol. 28:125152. https://doi.org/10.1080/07388550802107202.

Han, E. J., N. K. Lee, S. Y. Choi, and H. D. Paik. 2013. Short communication: Bacteriocin $\mathrm{KC} 24$ produced by Lactococcus lactis $\mathrm{KC} 24$ from kimchi and its antilisterial effect in UHT milk. J. Dairy Sci. 96:101-104. https://doi.org/10.3168/jds.2012-5884.

Henning, C., D. Gautam, and P. Muriana. 2015. Identification of multiple bacteriocins in Enterococcus spp. using an Enterococcus-specific bacteriocin PCR array. Microorganisms 3:1-16. https://doi .org/10.3390/microorganisms3010001.

Heredia-Castro, P. Y., J. I. Mendez-Romero, A. Hernandez-Mendoza, E. Acedo-Felix, A. F. Gonzalez-Cordova, and B. Vallejo-Cordoba. 2015. Antimicrobial activity and partial characterization of bacteriocin-like inhibitory substances produced by Lactobacillus spp. isolated from artisanal Mexican cheese. J. Dairy Sci. 98:8285-8293. https://doi.org/10.3168/jds.2015-10104.

Hernández, D., E. Cardell, and V. Zarate. 2005. Antimicrobial activity of lactic acid bacteria isolated from Tenerife cheese: initial characterization of plantaricin TF711, a bacteriocin-like substance produced by Lactobacillus plantarum TF711. J. Appl. Microbiol. 99:77-84. https://doi.org/10.1111/j.1365-2672.2005.02576.x.
Hoover, D. G., and S. K. Harlander. 1993. Screening methods for detecting bacteriocin activity. Pages 23-29 in Bacteriocins of Lactic Acid Bacteria. D. G. Hoover and L. R. Steenson, ed. Academic Press, San Diego, CA. https://doi.org/10.1016/B978-0-12-355510 $-6.50010-5$

Hu, C. B., W. Malaphan, T. Zendo, J. Nakayama, and K. Sonomoto. 2010. Enterocin X, a novel two-peptide bacteriocin from Enterococcus faecium KU-B5, has an antibacterial spectrum entirely different from those of its component peptides. Appl. Environ. Microbiol. 76:4542-4545. https://doi.org/10.1128/AEM.02264-09.

Izquierdo, E., E. Marchioni, D. Aoude-Werner, C. Hasselmann, and S. Ennahar. 2009. Smearing of soft cheese with Enterococcus faecium WHE 81, a multi-bacteriocin producer, against Listeria monocytogenes. Food Microbiol. 26:16-20. https://doi.org/10.1016/j.fm .2008 .08 .002 .

Khan, H., S. Flint, and P. L. Yu. 2010. Enterocins in food preservation. Int. J. Food Microbiol. 141:1-10. https://doi.org/10.1016/j ijfoodmicro.2010.03.005.

Kim, O. S., Y. J. Cho, K. Lee, S. H. Yoon, M. Kim, H. Na, S. C. Park, Y. S. Jeon, J. H. Lee, H. Yi, S. Won, and J. Chun. 2012. Introducing EzTaxon-e: A prokaryotic 16S rRNA gene sequence database with phylotypes that represent uncultured species. Int. J. Syst. Evol. Microbiol. 62:716-721. https://doi.org/10.1099/ijs $.0 .038075-0$.

Kumar, S., G. Stecher, and K. Tamura. 2016. MEGA7: Molecular Evolutionary Genetics Analysis version 7.0 for bigger datasets. Mol. Biol. Evol. 33:1870-1874. https://doi.org/10.1093/molbev/ msw054.

Kumari, A., N. Akkoc, and M. Akcelik. 2012. Purification and partial characterization of bacteriocin produced by Lactococcus lactis ssp. lactis LL171. World J. Microbiol. Biotechnol. 28:1647-1655. https://doi.org/10.1007/s11274-011-0971-4.

Maidak, B. L., J. R. Cole, C. T. Parker Jr., G. M. Garrity, N. Larsen, B. Li, T. G. Lilburn, M. J. McCaughey, G. J. Olsen, R. Overbeek, S. Pramanik, T. M. Schmidt, J. M. Tiedje, and C. R. Woese. 1999. A new version of the RDP (Ribosomal Database Project). Nucleic Acids Res. 27:171-173. https://doi.org/10.1093/nar/28.1.173.

Maky, M. A., N. Ishibashi, T. Zendo, R. H. Perez, J. R. Doud, M. Karmi, and K. Sonomoto. 2015. Enterocin F4-9, a novel O-linked glycosylated bacteriocin. Appl. Environ. Microbiol. 81:4819-4826. https://doi.org/10.1128/AEM.00940-15.

Mayr-Harting, A., A. J. Hedges, and R. C. W. Berkeley. 1972. Methods for studying bacteriocins. Pages 315-422 in Methods in Microbiology. Vol. 7. J. R. Norris and D. W. Ribbons, ed. Academic Press, New York, NY. https://doi.org/10.1016/s0580-9517(08)70618-4.

Myers, E. W., and W. Miller. 1988. Optimal alignments in linear space. Comput. Appl. Biosci. 4:11-17. https://doi.org/10.1093/ bioinformatics/4.1.11.

O'Keeffe, T., C. Hill, and R. P. Ross. 1999. Characterization and heterologous expression of the genes encoding enterocin a production, immunity, and regulation in Enterococcus faecium DPC1146. Appl. Environ. Microbiol. 65:1506-1515.

Ogaki, M. B., K. R. Rocha, M. R. Terra, M. C. Furlaneto, and L. F. Maia. 2016. Screening of the enterocin-encoding genes and antimicrobial activity in Enterococcus species. J. Microbiol. Biotechnol. 26:1026-1034. https://doi.org/10.4014/jmb.1509.09020.

Oman, T. J., J. M. Boettcher, H. Wang, X. N. Okalibe, and W. A. van der Donk. 2011. Sublancin is not a lantibiotic but an S-linked glycopeptide. Nat. Chem. Biol. 7:78-80. https://doi.org/10.1038/ nchembio. 509

Park, S. H., K. Itoh, and T. Fujisawa. 2003. Characteristics and identification of enterocins produced by Enterococcus faecium JCM 5804T. J. Appl. Microbiol. 95:294-300. https://doi.org/10.1046/j .1365-2672.2003.01975.x.

Perez, R. H., K. Himeno, N. Ishibashi, Y. Masuda, T. Zendo, K. Fujita, P. Wilaipun, V. Leelawatcharamas, J. Nakayama, and K. Sonomoto. 2012. Monitoring of the multiple bacteriocin production by Enterococcus faecium NKR-5-3 through a developed liquid chromatography and mass spectrometry-based quantification system. J. Biosci. Bioeng. 114:490-496. https://doi.org/10.1016/j .jbiosc.2012.06.003. 
Pinto, A. L., M. Fernandes, C. Pinto, H. Albano, F. Castilho, P. Teixeira, and P. A. Gibbs. 2009. Characterization of anti-Listeria bacteriocins isolated from shellfish: Potential antimicrobials to control non-fermented seafood. Int. J. Food Microbiol. 129:50-58. https:/ doi.org/10.1016/j.ijfoodmicro.2008.11.005.

Quigley, L., O. O'Sullivan, C. Stanton, T. P. Beresford, R. P. Ross, G. F. Fitzgerald, and P. D. Cotter. 2013. The complex microbiota of raw milk. FEMS Microbiol. Rev. 37:664-698. https://doi.org/10 $.1111 / 1574-6976.12030$.

Rainey, F. A., N. Ward-Rainey, R. M. Kroppenstedt, and E. Stackebrandt. 1996. The genus Nocardiopsis represents a phylogenetically coherent taxon and a distinct actinomycete lineage: Proposal of Nocardiopsaceae fam. nov. Int. J. Syst. Bacteriol. 46:1088-1092. https://doi.org/10.1099/00207713-46-4-1088.

Stepper, J., S. Shastri, T. S. Loo, J. C. Preston, P. Novak, P. Man, C. H. Moore, V. Havlicek, M. L. Patchett, and G. E. Norris. 2011. Cysteine S-glycosylation, a new post-translational modifica- tion found in glycopeptide bacteriocins. FEBS Lett. 585:645-650 https://doi.org/10.1016/j.febslet.2011.01.023.

Tagg, J. R., and A. R. McGiven. 1971. Assay system for bacteriocins. Appl. Microbiol. 21:943.

Vasilchenko, A. S., E. A. Rogozhin, and A. V. Valyshev. 2017. Purification of a novel bacteriocin-like inhibitory substance produced by Enterococcus faecium ICIS 8 and characterization of its mode of action. Microb. Drug Resist. 23:447-456. https://doi.org/10.1089/ mdr.2016.0069.

Vimont, A., B. Fernandez, R. Hammami, A. Ababsa, H. Daba, and I. Fliss. 2017. Bacteriocin-producing Enterococcus faecium LCW 44 A high potential probiotic candidate from raw camel milk. Front. Microbiol. 8:865. https://doi.org/10.3389/fmicb.2017.00865.

Zhu, W. M., W. Liu, and D. Q. Wu. 2000. Isolation and characterization of a new bacteriocin from Lactobacillus gasseri KT7. J. Appl. Microbiol. 88:877-886. https://doi.org/10.1046/j.1365-2672.2000 $.01027 . x$ 